\title{
Pembaruan Hukum Penentuan Faktor Penyesuaian Sewa Barang Milik Daerah oleh Pemerintah Daerah
}

\author{
Muhajir dan M. Najih $^{* *}$ \\ muhajirub@gmail.com \\ "Universitas Brawijaya \\ **Universitas Muhammadiyah Malang
}

\begin{abstract}
Keywords: $\quad$ Abstract
Legal update; This study wants to see how the legal problems in determining the factors that adjust Regional Property the BMD rental and legal politics of norms in the future. This research uses normative Rental; Local legal research. The results of the study show that there is a legal discovery at the level of government. Permendagri 19/2016. As an implementing regulation for BMD and becoming an NSPK by the local government, Permendagri 19/2016 still does not have a rigid norm regulating the rent-adjusting factor. Legal reforms need to be carried out, among others, by: 1 . to provide legal certainty for the separation between the BMD and BMN regimes firmly; 2 . strengthening the role of the central government as a supervisor for local governments; 3. Local governments are free to seek legitimate financial opinions through (PAD). The advice given to the Ministry of Home Affairs is to revise Permendagri 19/2016 by incorporating the norms for rent-adjusting factors by adopting the norms contained in the Regulation of the Minister of Finance Number 115/PMK.06/2020 concerning Utilization of State Property.
\end{abstract}

Kata Kunci:
Pembaruan
Hukum;
Sewa Barang
Milik Daerah;
Pemerintah
Daerah.

Abstrak

Penelitian ini ingin meilihat bagaimana permasalahan hukum dalam penetapan faktor penyesuai sewa BMD oleh pemerintah daerah dan politik hukum pembaharuan norma di masa mendatang. Pengkajian hal mengenai hal tersebut tergolong baru, karena belum pernah ada penelitian sebelumnya yang mengkaji pengaturan sewa BMD khususnya dalam Permendagri 19/2016. Penelitian ini menggunakan penelitian hukum normatif. Hasil penelitian menunjukakan bahwa terjadi kekosongan hukum dalam level Permendagri 19/2016. Sebagai peraturan pelaksana BMD dan menjadi NSPK oleh pemerintah daerah, Permendagri 19/2016 masih belum memiliki norma yang rigid mengatur tentang faktor penyesuai sewa. Permendagri 19/2016 tidak sampai mengatur tentang peruntukan hingga penghitungan terhadap jenis-jenis kegiatan usaha yang memanfaatkan BMD. Pembaruan hukum perlu dilakukan antara lain dengan adalah: 1. memberikan kepastian hukum pemisahan antara rezim BMD dan BMN secara tegas; 2 . memperkuat peran pemerintah pusat sebagai pembina pemerintah daerah; 3. Pemerintah daerah bebas untuk mencari pendapat keuangan yang sah melalui (PAD). Saran diberikan kepada Kementrian Dalam Negeri untuk melakukan revisi terhadap Permendagri 19/2016 dengan memasukkan norma faktor penyesuai sewa dengan mengadopsi norma yang ada dalam Peraturan Menteri Keuangan Nomor 115/PMK.06/2020 Tentang Pemanfaatan Barang Milik Negara. 
Muhajir dan M. Najih: Pembaruan Hukum Penentuan...

\section{Pendahuluan}

Pengelolaan Barang Milik Daerah (BMD) diatur dalam Peraturan Menteri Dalam Negeri Nomor 19 tahun 2016 tentang Pengelolaan Barang Milik Daerah (Permendagri 19/2016). Pengelolaan barang milik daerah adalah keseluruhan kegiatan yang meliputi perencanaan kebutuhan dan penganggaran, pengadaan, penggunaan, pemanfaatan, pengamanan dan pemeliharaan, penilaian, pemindahtanganan, pemusnahan, penghapusan, penatausahaan, pembinaan, pengawasan, dan pengendalian. ${ }^{1}$ Permendagri tersebut adalah sebagai pelaksana ketentuan Pasal 59 ayat (3), ${ }^{2}$ dan Pasal 90. ${ }^{3}$ Peraturan Pemerintah Nomor 27 Tahun 2014 tentang Pengelolaan Barang Milik Negara/Daerah (PP 27/2014), sehingga Menteri Dalam Negeri berwenang menetapkan kebijakan pengelolaan barang milik daerah. PP tersebut juga merupakan, aturan lebih lanjut dari ketentuan Pasal 49 ayat (6) Undang-Undang Nomor 1 Tahun 2004 tentang Perbendaharaan Negara, ${ }^{4}$ dimana perlu menetapkan Peraturan Pemerintah tentang Pengelolaan Barang Milik Negara/Daerah.

Berdasarkan pasal 90 Peraturan Pemerintah Nomor 27 Tahun 2014, kewenangan tersebut diatur lebih lanjut dalam peraturan menteri keuangan dan menteri dalam negeri. Mengenai menteri dalam negeri, dijelaskan: Menteri Dalam Negeri melakukan pembinaan pengelolaan BMD dan menetapkan kebijakan sesuai dengan kebijakan umum sebagaimana dimaksud pada ayat (2). Sedangkan menteri keuangan dijelaskan: Menteri Keuangan melakukan pembinaan pengelolaan Barang Milik

${ }^{1}$ Agus Purnomo, 'Analisis Pengelolaan Barang Milik Daerah Dalam Meningkatkan Pendapatan Asli Daerah' (2021) 7 Jurnal Kebijakan dan Pelayanan Publik.

${ }^{2}$ Ayat 1. Pemindahtanganan BMD selain tanah dan/atau bangunan yang bernilai sampai dengan Rp5.000.000.000,00 (lima miliar rupiah) dilakukan oleh Pengelola Barang setelah mendapat persetujuan Gubernur/Bupati/Walikota. 2.Pemindahtanganan BMD selain tanah dan/atau bangunan yang bernilai lebih dari Rp5.000.000.000,00 (lima miliar rupiah) sebagaimana dimaksud dalam Pasal 56 ayat (2) huruf b dilakukan oleh Pengelola Barang setelah mendapat persetujuan Dewan Perwakilan Rakyat Daerah. 3. Usul untuk memperoleh persetujuan Dewan Perwakilan Rakyat Daerah sebagaimana dimaksud pada ayat (2) diajukan oleh Gubernur/Bupati/Walikota sesuai dengan pedoman yang ditetapkan oleh Menteri Dalam Negeri.

${ }^{3}$ Ayat 1 Menteri Keuangan melakukan pembinaan pengelolaan Barang Milik Negara dan menetapkan kebijakan pengelolaan Barang Milik Negara/Daerah. 2.Kebijakan sebagaimana dimaksud pada ayat (1) terdiri atas kebijakan umum Barang Milik Negara/Daerah dan/atau kebijakan teknis Barang Milik Negara. 3.Menteri Dalam Negeri melakukan pembinaan pengelolaan BMD dan menetapkan kebijakan sesuai dengan kebijakan umum sebagaimana dimaksud pada ayat (2).

${ }^{4}$ Ketentuan mengenai pedoman teknis dan administrasi pengelolaan barang milik negara/ daerah diatur dengan peraturan pemerintah. 
Negara dan menetapkan kebijakan pengelolaan Barang Milik Negara/Daerah. Hasfi menegaskan, dengan perangkat peraturan tersebut, maka sudah sangat jelas bahwa BMD adalah salah satu pemasukan yang sah sesuai UU Perimbangan Kekuasaan antara Pemerintah Pusat dan Daerah. ${ }^{5}$

Pemerintah daerah dapat memanfaatkan BMD sesuai dengan PP 27/2014 dan juga Permendagri 19/2016, melalu beberapa bentuk: 1) Sewa; 2) Pinjam pakai; 3) Kerja sama pemanfaatan; 4) Bangun Guna Serah; atau 5) Kerja sama penyediaan infrastruktur. Kembali pada pembahasan semula, bahwa pemerintah daerah diberikan ruang gerak untuk mencari dan menerima manfaat dari segala macam keuntungan kekuangan selama itu berdasarkan pada peraturan perundangundangan, salah satunya adalah pemanfaatan BMD (BMD). ${ }^{6}$ Selain memanfaatkan, pemerintah daerah juga memiliki kuasa untuk menghapuskan BMD penghapusan BMD melalui, agar menjadi manfaat melalu jual beli. ${ }^{7}$

BMD dalam hukum positif saat ini diatur dalam peraturan induk selevel undang-undang dalam UU Perbendaharaan Negara. Dalam pasal 1 ayat (11) UU Perbendaharaan Negara: BMD adalah semua barang yang dibeli atau diperoleh atas beban APBD atau berasal dari perolehan lainnya yang sah. Lebih lanjut mengenai BMD diatur dalam pasal 49 ayat (6). Sebagaimana peraturan induk selevel undangundang, maka keberadaan norma ini membutuhkan implementasi dalam peraturan pelaksana, yang kemudian diatur lebih spesifik salah satunya dalam level Peraturan Pemerintah Nomor 27 Tahun 2014 tentang Pengelolaan Barang Milik Negara/Daerah. Salah satu permasalahan dalam skema pemanfaatan adalah mengenai pemanfaatan sewa, khususnya yakni penentuan formula tarif sewa.

Fokus utama dalam penelitian ini adalah kajian terhadap Barang Milik Daerah, khususnya mengenai norma tentang formula tarif sewa. BMD sebagai

\footnotetext{
${ }^{5}$ Nyemas Hasfi, 'Pengelolaan Barang Milik Daerah (Suatu Studi Pada Dinas Pendapatan, Pengelolaan Keuangan dan Aset Kabupaten Sintang)' (2013) 1 Jurnal Tesis PMIS UNTAN PSIAN.

${ }^{6}$ Imam Mulyono Siti Amerieska, Fita Setiati, 'Analisis Faktor Tentang Efektivitas Pengelolaan Barang Milik Daerah (Studi pada Badan Pengelolaan Keuangan ddn Aset Daerah Kabupaten Malang)' (2018) 1 Jurnal Ilmiah Bisnis dan Ekonomi Asia.

7 JA Conway, F., Kaganova, O., \& McKellar, Composite Image of Central Government Asset Management Reforms (Managing government property assets: International experiences 2006).[125].
} 
kekayaan daerah, dimana kekayaan itu boleh dimanfaatkan agar menjadi pemasukan bagi pemerintah daerah yang sah. Dalam mengambil pemanfaatan, ${ }^{8}$ maka melalui prosedur sewa oleh pihak ketiga/masyrakat/badan hukum/ usaha. Dalam penentuan tarif sewa, maka yang menentukan tarif sewa adalah pemerintah daerah, dan dalam penentuan itu, maka Pemerintah daerah wajib tunduk dan patuh pada NSPK (Norma Standar Prosedur dan Kriteria) yang diatur oleh pemerintah pusat, yang dalam hal ini adalah Kemendagri. Isu utama dalam penelitian ini adalah kekosongan hukum (recht vacum).

Isu hukum dalam kajian ini yakni Kekosongan hukum dalam Permendagri 19/2016. Dalam permendagri tersebut, tidak mengatur secara rigid tentang Faktor Penyesuai Sewa BMD, mulai dari besaran hingga metode penghitungan. Akhirnya, Permendagri ini tidak bisa menjadi landasan hukum untuk pemerintah daerah dalam membentuk produk hukum daerah sebagai payung formula tarif sewa BMD.

Sebagai contoh adalah Peraturan Bupati Karawang Nomor 90 tahun 2018 tentang Tata Cara Pelaksanaan Pemanfaatan Barang Milik Daerah. Peraturan tersebut, di dalamnya mencantumkan formula tarif sewa. Oleh karena Permendagri 19/2016 tidak memiliki norma yang rigid tentang formula tarif sewa, maka Perbup itu mengadopsi formula tarif sewa dan Faktor Penyesuai Sewa yang ada di Peraturan Menteri Keuangan Nomor: 57/PMK.06/2016 tentang Tata Cara Pelaksanaan Sewa Barang Milik Negara.

Menjadi masalah adalah, Perbup itu merujuk pada Peraturan Menteri Keuangan Nomor: 57/PMK.06/2016 tentang Tata Cara Pelaksanaan Sewa Barang Milik Negara, yang rezimnya merupakan Barang Milik Negara (BMN), yang berbeda dengan BMD. Hemat penulis, Permendagri 19/2016 belum dapat menjadi NSPK (Norma Standar Prosedur dan Kriteria) yang kuat bagi pemerintahan daerah dalam menentukan menentukan Faktor Penyesuai Sewa, karena didalamnya tidak ada norma mengenai Faktor Penyesuai Sewa yang rigid. oleh karena itu,

\footnotetext{
${ }^{8}$ Nunung Runiawati, 'Pemanfaatan Barang Milik Daerah (Suatu pendekatan teoritis dan praktis dalam menentukan metode pemanfaatan aset)’ (2017) 1 Jurnal Manajemen Pelayanan Publik.[45].
} 
potensi adanya pemasukan yang tidak sah kepada pemerintah daerah sangat dimungkinkan terjadi, hal ini dikarenakan landasan hukum pemerintah daerah dalam penentuan tarif sewa tidak memiliki dasar hukum yang pasti dan jelas sesuai dengan ketentuan hukum positif yang berlaku. Berdasarkan pada jabaran pendahuluan diatas, maka dalam penelitian ini dirumuskan masalah, antara lain: Problem hukum dalam ketentuan penetapan faktor penyesuai sewa BMD oleh pemerintah daerah dan politik hukum pembaharuan norma faktor penyesuai sewa BMD oleh pemerintah di masa mendatang?.

Penelitian ini merupakan penelitian orisinal dan mempunyai daya manfaat yang jelas. Namun untuk menunjang keberhasilan penelitian, penelitian ini tetap mengacu pada sumber-sumber terkait yang mendukung. Pertama, tulisan dari Nunung Runiawati mengenai "Pemanfaatan Barang Milik Daerah (Suatu Pendekatan Teoritis Dan Praktis Dalam Menentukan Metode Pemanfaatan Aset)" wajib untuk dirujuk karena memiliki gagasan yang kuat khususnya dalam metodemetode pemanfaatan aset daerah. Kemudian tulisan dari Era Nandya F, Jayus, dan Rosita Indrayanti tentang “Pengelolaan Barang Milik Daerah Berdasarkan Peraturan Pemerintah Nomor 27 Tahun 2014 Tentang Pengelolaan Barang Milik Negara/ Daerah", tulisan ini menjelaskan kaidah-kaidah dasar dalam pengelolaan BMD. Dari hal itu, di sisi lain terlihat jelas bahwa penelitian ini berbeda dengan penelitian sebelumnya karena mengkaji sewa BMD dalam kerangka hukum Permendagri 19/2016. Manfaat dari penelitian ini adalah untuk memberikan kerangka pengaturan baru, khususnya pada Kementrian Dalam Negeri untuk melakukan revisi terhadap Permendagri 19/2016 dengan memasukkan norma faktor penyesuai sewa dengan mengadopsi norma yang ada dalam Peraturan Menteri Keuangan Nomor 115/ PMK.06/2020 Tentang Pemanfaatan Barang Milik Negara.

\section{Metode Penelitian}

Penelitian ini merupakan penelitian hukum normatif. Penelitian hukum normatif merupakan penelitian yang difokuskan untuk mengkaji kaidah 
Muhajir dan M. Najih: Pembaruan Hukum Penentuan...

atau norma pada hukum positif. ${ }^{9}$ Penelitian ini merupakan penelitian hukum normative. Penelitian hukum normatif merupakan penelitian yang difokuskan untuk mengkaji kaidah atau norma pada hukum positif. Pendekatan dalam penelitian ini ialah pendekatan peraturan perundang-undangan (statue approach) dan pendekatan konseptual (conseptual apporoach). Metode interprestasi yang digunakan dalam penelitian ini yaitu: interprestasi gramatikal; interprestasi sistematik; interprestasi futuristik.

\section{Ketentuan Penetapan Faktor Penyesuai Sewa BMD oleh Pemerintah Daerah}

Perkembangan desentralisasi, telah melokalisasi kewenangan pemerintah pusat menjadi kewenangan pemerintah daerah yang mencakup otonomi daerah untuk mengelola barang milik daerah. ${ }^{10}$ Salah satu bentuk otonomi, adalah pemerintah daerah memiliki keleluasaan untuk menentukan besaran tarif sewa dengan tetapi berpedoman pada peraturan perundang-undangan yang berlaku. ${ }^{11}$ Metode penghitungan tarif sewa BMD oleh pemerintah daerah kepada pihak ketiga adalah metode yang muncul dalam level peraturan menteri. Dalam peraturan pemerintah dan undang-undang hal itu tidak diatur. Jika membuka kembali PP 27/2014, didalamnya hanya sampai mengatur tentang kewenangan penetapan yang ditetapkan oleh kepala daerah. Dalam pasal 29 PP 27/2014 ditegaskan: Formula tarif/besaran Sewa Barang Milik Negara/Daerah berupa tanah dan/atau bangunan ditetapkan oleh: Pengelola Barang, untuk Barang Milik Negara; atau Gubernur/Bupati/Walikota, untuk Barang Milik Daerah. Dalam bagian penjelasan, hal ini dijelaskan yakni khususnya mengenai formula tarif sewa: perhitungan nilai Sewa dengan cara mengalikan suatu indeks tertentu dengan nilai Barang Milik Negara/Daerah. Kemudian, yang dimaksud dengan "besaran Sewa" adalah besaran nilai nominal Sewa Barang Milik Negara/Daerah yang ditentukan.

\footnotetext{
${ }^{9}$ Johny Ibrahim, Teori dan Metodologi Penelitian Hukum Normatif (Bayumedia 2011).[295].

${ }^{10}$ Rosita Indrayati Era Nandya Febriana, Jayus, 'Pengelolaan Barang Milik Daerah Berdasarkan Peraturan Pemerintah Nomor 27 Tahun 2014 tentang Pengelolaan Barang Milik Negara/Daerah' (2017) 4 Journal Lentera Hukum.[135].

${ }^{11}$ Evi Noviawati, ‘Optimalisasi Pengelolaan Aset Daerah terhadap Penyelenggaraan Otonomi Daerah’ (2016) 4 Jurnal Galuh Justisi.[47].
} 
Ketentuan norma yang mengatur tentang metode penghitungan, yang dalam PP masih bersifat genus, kemudian diatur lebih lanjut dalam Permendagri 19/2016 untuk BMD dan Permenkeu 115/PMK.06/2020 untuk BMN.

Dalam metode penghitungan BMD, yang diatur dalam Permendagri 19/2016 terdapat beberapa metode penghitungan besaran tarif sewa BMD. Formula tarif/ besaran sewa barang milik daerah ditetapkan oleh Gubernur/Bupati/Walikota untuk barang milik daerah berupa tanah dan/atau bangunan; dan untuk barang milik daerah berupa selain tanah dan/atau bangunan dengan berpedoman pada kebijakan pengelolaan barang milik daerah. Permendagri memberikan spesialisasi kepada penyewa berupa kerjasama pembangunan infrastruktur (KSPI), wajib mempertimbangkan nilai keekonomian dari masing-masing jenis infrastruktur. Pertimbangan tersebut yakni, pertimbangan terhadap daya beli/kemampuan membayar (ability to pay) masyarakat dan/atau kemauan membayar (willingness to pay) masyarakat. Untuk menghitung berapa besaran formula tarif sewa, maka metodenya adalah perkalian dari tarif pokok sewa $x$ faktor penyesuai sewa.

Bagan 1. Metode Penghitungan BMD

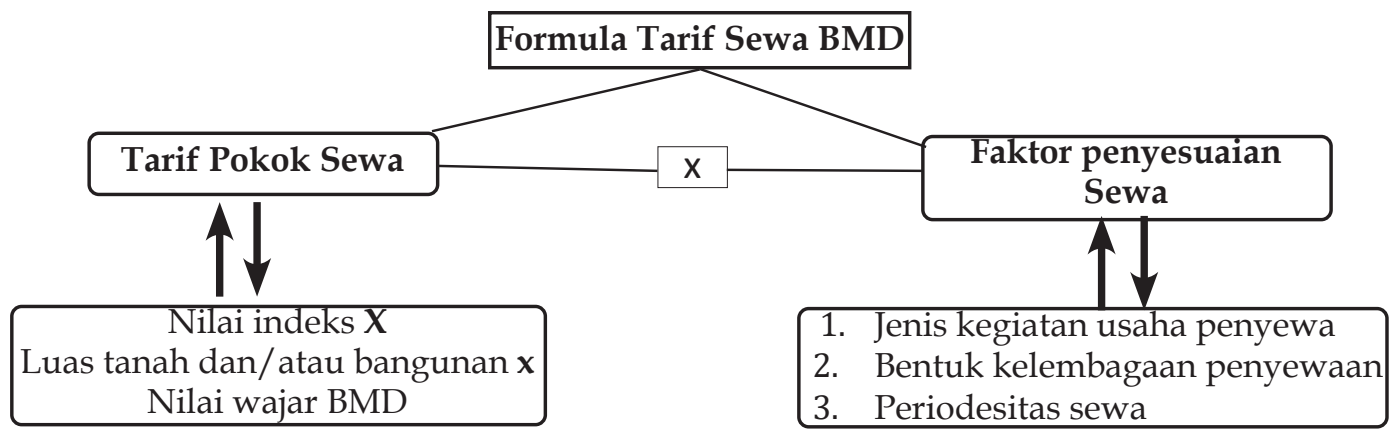

Terdapat dua komponen untuk menghitung formula tarif sewa yakni tarif pokok sewa dan faktor penyesuai sewa. Tarif pokok sewa adalah hasil penghitungan perkalian dari nilai indeks, luas tanah dan nilai wajar. Untuk komponen ini, dalam Permendagri 19/2016 diatur dengan rigid dalam pasal 116125 Permendagri 19/2016. Sehingga komponen tersebut hemat penulis, dapat diaplikasikan dengan mudah karena tinggal memasukan angka/kuantitas pada komponen-komponen tersebut. 
Muhajir dan M. Najih: Pembaruan Hukum Penentuan...

Tabel 1. Formula Tarif Sewa BMD

Pasal 117:

Formula tarif sewa barang milik daerah merupakan hasil perkalian dari: tarif pokok sewa; dan faktor penyesuai sewa.

\section{Tarif Pokok Sewa}

Pasal 118

1. Tarif pokok sewa sebagaimana dimaksud dalam Pasal 117 huruf a adalah hasil perkalian antara nilai indeks barang milik daerah dengan luas tanah dan/atau bangunan dan nilai wajar tanah dan/atau bangunan.

2. Tarif pokok sewa sebagaimana dimaksud pada ayat (1), dibedakan untuk:

a. barang milik daerah berupa tanah;

b. barang milik daerah berupa bangunan;

c. barang milik daerah berupa sebagian tanah dan bangunan; dan

d. barang milik daerah selain tanah dan/ atau bangunan.

3. Tarif pokok sewa barang milik daerah berupa tanah dan/atau bangunan sebagaimana dimaksud pada ayat (2) huruf a, huruf b dan huruf c dapat termasuk formula sewa barang milik daerah berupa prasarana bangunan.

4. Tarif pokok sewa barang milik daerah ditetapkan oleh Gubernur/Bupati/Walikota.

\section{Faktor Penyesuai Sewa}

Pasal 126

1. Faktor penyesuai sewa sebagaimana dimaksud dalam Pasal 117 huruf $b$ meliputi

a. jenis kegiatan usaha penyewa;

b. bentuk kelembagaan penyewa; dan

c. periodesitas sewa.

2. Faktor penyesuai sewa sebagaimana dimaksud pada ayat (1) dihitung dalam persentase.

3. Faktor penyesuai sewa sebagaimana dimaksud pada ayat (1) ditetapkan oleh Gubernur/Bupati/Walikota.

Berikutnya adalah faktor penyesuai sewa, Permendagri 19/2016 tidak mengatur lebih detail tentang metode penghitungan faktor penyesuai sewa. Komponen kedua ini hanya diatur dalam 1 pasal, yakni pasal 126, yang berbunyi: 1. Faktor penyesuai sewa sebagaimana dimaksud dalam Pasal 117 huruf b meliputi: a. jenis kegiatan usaha penyewa; b. bentuk kelembagaan penyewa; dan c. periodesitas sewa. 2. Faktor penyesuai sewa sebagaimana dimaksud pada ayat (1) dihitung dalam persentase.

3. Faktor penyesuai sewa sebagaimana dimaksud pada ayat (1) ditetapkan oleh Gubernur/Bupati/Walikota. Penghitungan dan penetapan tentang jumlah/angka faktor penyesuai sewa ini, berdasarkan Permendagri 19/2016 langsung diberikan kepada kepala daerah tanpa adanya metode penghitungan lebih lanjut.

Jika dibandingkan dengan metode penghitungan BMD oleh Menteri Keuangan, maka metode penghitungan tarif sewa BMN terbilang lengkap dan jelas jika dibandingkan BMD. Dalam Permenkeu 115/PMK.06/2020, metode penghitungan sewa BMN sama dengan BMD, yakni merupakan perkalian tarif pokok sewa $\mathrm{x}$ faktor penyesuai sewa. 
Bagan 2. Metode Penghitungan BMN

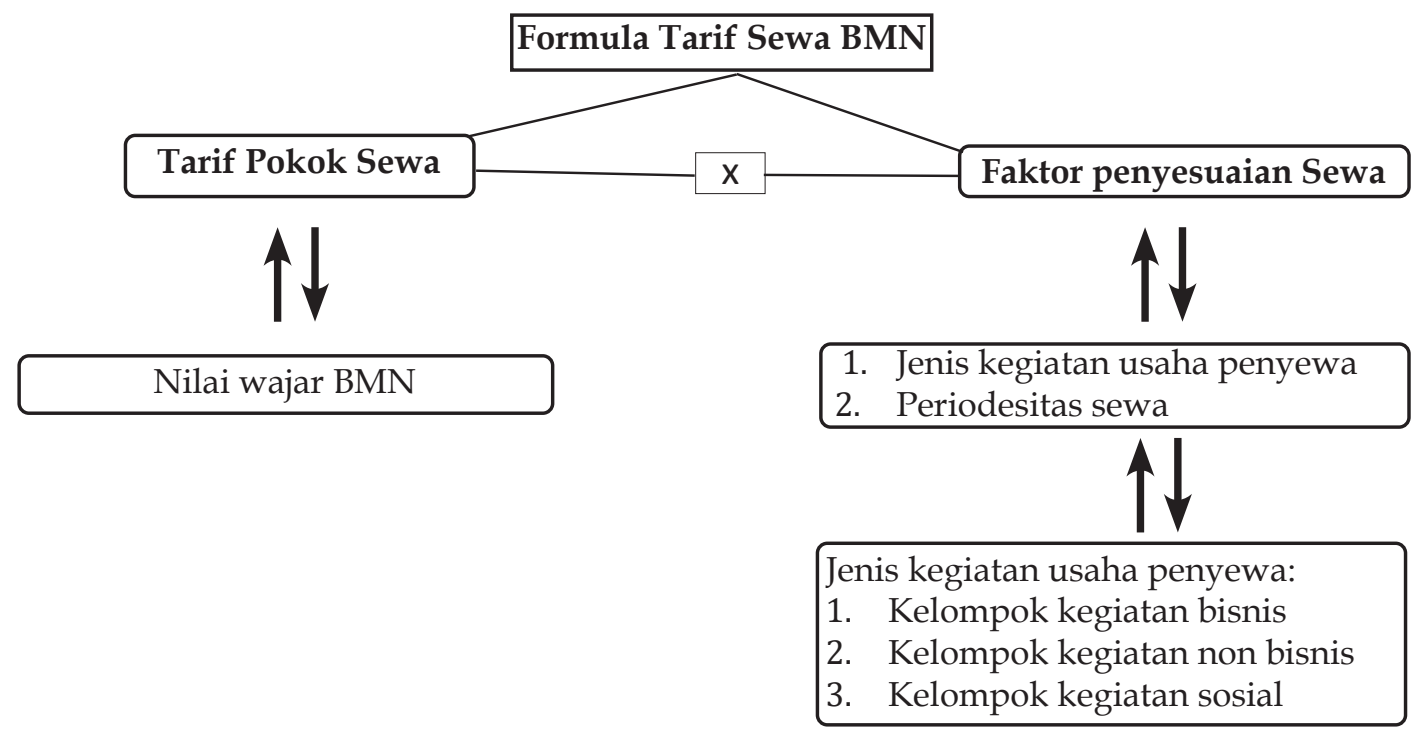

Menjadi perbedaan antara metode penghitungan BMD dan BMN adalah dalam faktor penyesuai sewanya. Jika dalam BMN, faktor penyesuai sewa diklasifikasikan lebih rigid ke dalam 3 sektor jenis kegiatan usaha, yakni kelompok bisnis, non bisnis dan sosial. Klasifikasi tersebut, dalam Permenkeu 115/PMK.06/2020 juga mencantumkan penetapan faktor penyesuai sewa dalam bentuk persenan, yakni $100 \%$ untuk kegiatan usaha bisnis, 30-50 \% untuk kegiatan non-bisnis dan 2,5\% untuk kegiatan sosial. Selain jenis kegiatan usaha, mengenai penghitungan periodesitas sewa juga diatur secara rigid dalam penghitungan BMN, dalam pasal 21 Permenkeu 115/PMK.06/2020, yakni:

1. untuk jangka waktu Sewa 1 (satu) tahun: 1. per tahun sebesar $100 \%$ (seratus persen); 2. per bulan sebesar 130\% (seratus tiga puluh persen); 3. per hari sebesar 160\% (seratus enam puluh persen); 4. per jam sebesar 190\% (seratus sembilan puluh persen).

2. Untuk jangka waktu Sewa lebih dari 1 (satu) tahun: 1 . sebesar $100 \%$ (seratus persen) untuk pembayaran Sewa yang dilakukan sekaligus terhadap seluruh jangka waktu Sewa; 2. sebesar 120\% (seratus dua puluh persen) untuk pembayaran Sewa yang dilakukan per tahun terhadap Sewa yang berjangka waktu 2 (dua) tahun; 3. sebesar 125\% (seratus dua puluh lima persen) untuk pembayaran Sewa yang dilakukan per tahun terhadap Sewa yang berjangka 
Muhajir dan M. Najih: Pembaruan Hukum Penentuan...

waktu 3 (tiga) tahun; 4. sebesar 130\% (seratus tiga puluh persen) untuk pembayaran Sewa yang dilakukan per tahun terhadap Sewa yang berjangka waktu 4 (empat) tahun; 5. sebesar 135\% (seratus tiga puluh lima persen) untuk pembayaran Sewa yang dilakukan per tahun terhadap Sewa yang berjangka waktu 5 (lima) tahun.

Berdasarkan pada uraian diatas, maka dipahami bahwa Permendagri 19/2016 yang merupakan NSPK bagi pemerintah daerah dalam melakukan aksi pemanfaatan sewa BMD dan juga sebagai landasan pembentukan regulasi daerah, masih belum sepenuhnya mengakomodasi tentang metode penghitungan formula tarif sewa BMD secara rigid, khususnya dalam komponen faktor penyesuai sewa, yang norma dalam Permendagri tersebut masih sangat abstrak dan sulit dioperasionalkan.

Dalam uraian yang dijelaskan sebelumnya, oleh karena terdapat kekosongan hukum mengenai faktor penyesuai sewa BMD, maka terjadi beberapa problem di level pemerintahan daerah. Pertama, Tidak ada keseragaman dan kesamaan standar antara satu pemerintah daerah dengan lainnya. Salah satu kewajiban penyelenggaran pemerintahan adalah melakukan aksi pemerintah berdasarkan pada asas-asas umum pemerintahan yang baik (AAUPB), yang salah satu asasnya adalah kepastian hukum. Kepastian hukum dalam tindakan pemerintahan dimaknai keseragaman tindak dan kebijakan. Jika dalam di satu daerah pemerintah menetapkan kebijakan terentu dengan model A, maka di tempat lain juga harus menggunakan model A. Dalam hal ini, artrinya penerapan suatu kebijakan tertentu yang merupakan atribusi dari pemerintahan pusat dapat dilakukan secara seragam di seluruh daerah di Indonesia. Apa urgensi keseragaman tersebut? Untuk menghindari perbedaan perlakuan/diskriminasi. Jika melihat aspek pemanfaatan daerah, salah satu subjek pemanfaatan adalah badan hukum/usaha yang sifatnya adalah multiregional, seperti Badan Usaha Milik Negara (BUMN) yang melakukan beberapa kegiatan di beberapa daerah. Jika tidak ada keseragaman aksi pemerintah dalam penetapan tarif sewa, maka potensi BUMN tersebut diperlakukan berbeda antara daerah satu dengan daerah lainnya sangat terbuka. 
Dalam status quo, memang terdapat beberapa daerah yang menggunakan Permenkeu 115/PMK.06/2020 sebagai rujukan dasar metode pengitungan tarif sewa dan kemudian dijadikan sebagai dasar yuridis pembentukan Perda yang mengatur pemanfaatan BMD. Akan tetapi hal ini tentunya tidak dilakukan oleh semua pemerintah daerah, dalam batas penalaran yang wajar hal ini disebabkan keraguan untuk menjadikan Permenkeu 115/PMK.06/2020 sebagai dasar metode yang dirujuk dan pembentukan perda lantaran Permenkeu 115/PMK.06/2020 adalah mengatur mengenai rezim BMN.

Kedua, Menghambat laju pembangunan dan perkembangan investasi di level pemerintah daerah. Dengan tidak adanya dasar pedoman penentuan tarif sewa BMD yang rigid, maka terjadi kelongaran bagi pemerintah daerah untuk menetapkan tarif sewa secara subjektif tanpa penghitungan yang ketat. Alhasil, hal ini menjadikan tarif sewa berbiaya tinggi dan kemudian menjadi hal yang memberatkan bagi para pemanfaat $\mathrm{BMD}$, terlebih para pemanfaat itu juga akan dikenakan retribusi atas pemanfaatan BMD sebagaimana ditegaskan dalam pasal 128 UU Pajak dan Retribus Daerah. Jika kemudian tarif sewa ini tidak terkontrol, maka dampaknya akan menghambat laju pembangunan dan investasi di tingkat daerah, dimana salah satu sarana pembangunan oleh para badan usaha/hukum itu adalah menggunakan dan mengambil manfaat dari BMD, seperti penyewaan tanah. Ketiga, Menjadikan setiap pemasukan daerah yang bersumber dari pemanfaatan BMD menjadi pemasukan yang tidak sah, lantaran tidak dilandasi dengan perangkat hukum yang jelas dan tegas.

\section{Pembaruan Hukum Penentuan Faktor Penyesuai Sewa BMD Oleh Pemerintah Daerah di Masa Mendatang}

Pemanfaatan BMD adalah dalam rangka untuk mencapai kepentingan umum dan kesejahteraan sebesar-besarnya. Pemasukan yang diterima dari pemanfaatan BMD, akan menjadi modal utama pemasukan pemerintah daerah untuk membangun kebijakan kesejahteraan bagia warga. Maka dari itu, peran hukum administrasi negara sangat besar untuk mejamin kelancaran proses tersebut. Secara garis besar menurut Stelinga, administrasi negara mempunyai 
Muhajir dan M. Najih: Pembaruan Hukum Penentuan...

kewenangan antara lain: (a) melakukan penetapan kebijakan, (b) melakukan pengaturan/regeling, (c) melakukan pengamanan, (d) melakukan peradilan, dan (e) melakukan pelayanan kepada warga negara. ${ }^{12}$ Sementara menurut Brown, kegiatan kepentingan umum adalah dilakukan dengan melakukan layanan publik yang merupakan kegiatan yang menggunakan kewenangan publik, dan dilakukan untuk memenuhi kepuasan kebutuhan publik. ${ }^{13}$

BMD merupakan unsur yang sangat penting dalam penyelenggaraan pemerintahan khususnya dalam memberikan pelayanan kepada masyarakat. Pemerintah harus melakukan pengelolaan atas barang milik daerah agar dapat berguna bagi pemerintah dan masyarakat. Pengelolaan barang milik daerah adalah suatu proses dalam mengelola kekayaan yang telah ada sebelumnya atau yang diperoleh dari beban APBN/D atau perolehan lainnya yang sah yang dapat dimanfaatkan dan digunakan dalam kegiatan pemerintah maupun masyarakat. BMD adalah sumber daya ekonomi yang dikuasai atau dimiliki oleh pemerintah Pusat/Daerah maka pengelolaan barang milik daerah tersebut harus dilakukan secara baik dan benar. ${ }^{14}$ Sebagai pemasukan, maka pendekatanya adalah juga menggunakan UU Perimbangan Kekuasan antara Pemerintah Pusat dan Daerah.

Landasan filosofis dari keberadaan UU Perimbangan Kekuasaan antara Pemerintah Pusat dan Daerah ini adalah: $:{ }^{15}$ bahwa hubungan keuangan, pelayanan umum, pemanfaatan sumber daya alam dan sumber daya lainnya antara Pemerintah Pusat dan Pemerintahan Daerah, dan antar Pemerintahan Daerah perlu diatur secara adil dan selaras; bahwa untuk mendukung penyelenggaraan otonomi daerah melalui penyediaan sumber-sumber pendanaan berdasarkan kewenangan Pemerintah Pusat, Desentralisasi, Dekonsentrasi, dan Tugas Pembantuan, perlu diatur perimbangan keuangan antara Pemerintah Pusat dan Pemerintahan Daerah

\footnotetext{
${ }^{12}$ Prajudi Atmosodirjo, Hukum Administrasi Negara (Ghalia Indonesia 1983).

${ }^{13}$ Safri Nugraha et. al., Hukum Administrasi Negara (Center for Law and Good Governance Studies FH UI 2007).

${ }^{14}$ Fikha Kristy Bolendea, et,al., 'Analisis Penggunanan Dan Penatausahaan Barang Milik Daerah Di Pemerintah Kota Manado’ (2017) 12 Jurnal Riset Akuntansi Going Concern.[1102-1112]. dan Daerah.

${ }^{15}$ Landasan Menimbang huruf b dan c UU Perimbangan Kekuasaan antara Pemerintah Pusat
} 
berupa sistem keuangan yang diatur berdasarkan pembagian kewenangan, tugas, dan tanggung jawab yang jelas antarsusunan pemerintahan.

Negara menyusun regulasi dalam rangka memberikan dorongan terhadap sektor ekonomi, begitu juga bagi pemerintah daerah. Regulasi pemerintah dapat memberikan dampak yang positif dan negatif pada proses inovasi dan daya saing. Titik tekan reformasi regulasi, dilakukan untuk memberikan pengaruh atau dampak positif terhadap inovasi dan daya saing. Reformasi regulasi diharapkan membantu memastikan bahwa peraturan perundang-undangan di semua bidang kegiatan sepenuhnya responsif terhadap perubahan kondisi ekonomi, sosial, dan teknologi yang mengelilinginya. Proses pengaturan memperhitungkan dampak dari regulasi yang berkaitan dengan inovasi serta implikasi dari perubahan teknologi untuk alasan dan desain regulasi. Regulasi dan reformasi regulasi dapat mempengaruhi teknologi serta dapat mempengaruhi proses inovasi. ${ }^{16}$

Dengan kehadiran UU ini, di dalamnya setiap pemerintah daerah memiliki ruang untuk mencari sumber-sumber pendapatan daerah melalui skema PD (Pendapatan daerah) dan PAD (Pendapatan Asli Daerah). ${ }^{17}$ Untuk PD ditegaskan dalam pasal 1 ayat (13): Pendapatan Daerah adalah hak Pemerintah Daerah yang diakui sebagai penambah nilai kekayaan bersih dalam periode tahun bersangkutan. Untuk PAD, hal ini ditegaskan dalam pasal 1 ayat (18) UU Perimbangan Kekuasaan antara Pemerintah Pusat dan Daerah: Pendapatan Asli Daerah, selanjutnya disebut PAD adalah pendapatan yang diperoleh Daerah yang dipungut berdasarkan Peraturan Daerah sesuai dengan peraturan perundang-undangan. ${ }^{18}$ Berdasarkan

\footnotetext{
${ }^{16}$ Robert W Hann, Reviving Regulatory Reform: A Global Perspective (AEI Brookings Joint Center for Regulatory Studies 2000).

${ }^{17}$ Junaidi A Devita, A Delis, 'Pengaruh Pendapatan Asli Daerah, Dana Alokasi Umum Dan Jumlah Penduduk Terhadap Belanja Daerah Kabupaten/Kota Di Provinsi Jambi’ (2014) 2 Jurnal Perspektif Pembiayaan dan Pembanguna Daerah.[63-70].

${ }^{18}$ Hal ini ditegaskan kembali dalam Pasal 2 UU Perimbangan Keuangan Pemerintah Daerah dan Pusat, yakni: (1) Perimbangan Keuangan antara Pemerintah dan Pemerintahan Daerah merupakan subsistem Keuangan Negara sebagai konsekuensi pembagian tugas antara Pemerintah dan Pemerintah Daerah. (2) Pemberian sumber keuangan Negara kepada Pemerintahan Daerah dalam rangka pelaksanaan Desentralisasi didasarkan atas penyerahan tugas oleh Pemerintah kepada Pemerintah Daerah dengan memperhatikan stabilitas dan keseimbangan fiskal. (3) Perimbangan Keuangan antara Pemerintah dan Pemerintahan Daerah merupakan suatu sistem yang menyeluruh dalam rangka pendanaan penyelenggaraan asas Desentralisasi, Dekonsentrasi, dan Tugas Pembantuan.
} 
ketentuan pasal ini, dapat dipahami dalam menjalankan/mencari/menerima setiap pendapatan daerah, harus didasarkan pada prosedur yang sah sesuai hukum: berdasarkan Peraturan Daerah sesuai dengan peraturan perundang-undangan, yang menggunakan instrumen pelaksana perda, dan perda tersebut diharuskan/ diwajibkan berkesesuaian dengan peraturan perundang-undangan lainya.

Oleh karena disyaratkan harus sesuai dengan peraturan perundangundangan yang berlaku, maka dalam ketentuan UU Perimbangan Kekuasaan antara Pemerintah Pusat dan Daerah, ${ }^{19}$ juga mengatur sumber penerimaan daerah yang diperbolehkan menurut undang-undang. Pasal 5 UU Perimbangan Keuangan Pemerintah Daerah dan Pusat, mengatur, Penerimaan Daerah dalam pelaksanaan Desentralisasi terdiri atas Pendapatan Daerah dan Pembiayaan, yang terdiri dari Pendapatan Asli Daerah; Dana Perimbangan; dan Lain-lain Pendapatan.

Selain diluar dari pada sumber-sumber tersebut, maka secara hukum hal itu tidak dibenarkan dan dianggap sebagai sumber tidak sah. Hal ini ditegaskan dalam pasal 1 ayat (18) UU Perimbangan Kekuasaan antara Pemerintah Pusat dan Daerah: Pendapatan Asli Daerah, selanjutnya disebut PAD adalah pendapatan yang diperoleh Daerah yang dipungut berdasarkan Peraturan Daerah sesuai dengan peraturan perundang-undangan.

Berdasarkan ketentuan pasal tersebut, terdapat beberapa pehamaman. Untuk mengkategorikan pemasukan daerah sebagai PAD, maka yang menjadi dasar rujukan adalah harus Peraturan Daerah setempat. Setiap aksi pemerintah harus ada pendahuluan dasar hukum berupa Peraturan Daerah, bukan hanya mengandalkan peraturan perundang-undangan diluar dari Perda, seperti PP, Permen dan UU. Perda adalah prasyarat mutlak daerah untuk mengambil manfaat dari setiap aksi pemerintah yang dalam hal ini adalah pemanfaatan. Untuk bisa mengambil manfaat dari BMD, maka harus ada Perda yang spesifik mengatur tentang BMD, jika hal ini tidak ada maka pemasukan dari pemanfaatan BMD itu adalah pemasukan yang tidak sah.

\footnotetext{
${ }^{19}$ Fitria Ningrum, ‘Penerapan Sistem Pengelolaan Barang Milik Daerah dan Kewajaran Laporan Keuangan Pemerintah Daerah’ (2017) 2 Jurnal Ekubis.
} 
Oleh karena pemerintah daerah diwajibkan untuk membuat Perda yang spesifik tentang BMD, maka Perda tersebut harus mengacu pada landasan peraturan diatasnya yang jelas dan spesifik mulai dari nama peraturan, asas hingga batang tubuh substansi. Hal ini untuk menjaga keteraturan, keharmonisan dan sinkronisasi norma dari level tertinggi hingga Perda yang akan dibentuk. Dalam bahasan sebelumnya, sudah diuraikan bahwa masalah yang timbul adalah dalam level peraturan menteri yang dalam hal ini adalah Permendagri terjadi kekosongan hukum dalam hal metode penghitungan formula tarif sewa. Atas masalah dalam status quo itu, maka pembaruan hukum tidak dihindari.

Pembaruan hukum dapat dilakukan dengan menggunakan politik hukum. Politik hukum setidaknya memiliki 3 dimensi, yakni masa lalu, sekarang dan masa depan. Politik hukum mengkaji apa saja permasalahan di masa lalu, menyaring masalah-masalah tersebut dan memprioritaskan mana yang akan diselesaikan. Masa kini adalah untuk memilih alternatif solusi untuk menyelesaikan dan kemudian merumuskan tujuan-tujuan apa yang hendak dicapai di masa mendatang. ${ }^{20}$ Penulis sejalan dengan pendapat yang bernas dari Padmo Wahjono, ia menjelaskan bahwa politik hukum adalah kebijakan dasar yang menentukan arah, bentuk, maupun isi hukum yang akan dibentuk. Dalam tulisannya yang lain Padmo Wahjono memperjelas definisi tersebut dengan mengatakan bahwa politik hukum adalah kebijakan penyelenggaraan Negara tentang apa yang dijadikan kriteria untuk menghukumkan suatu yang di dalamnya mencakup pembentukan, penerapan, dan penegakan hukum. ${ }^{21}$ Satjipto Rahardjo juga mendefinisikan politik hukum sebagai aktivitas memilih dan cara yang hendak dipakai untuk mencapai tujuan sosial dan hukum tertentu dalam masyarakat yang cakupannya meliputi jawaban atas beberapa pertanyaan mendasar, yaitu: Tujuan apa yang hendak dicapai melalui sistem yang ada; Cara-cara apa dan yang mana yang dirasa paling baik untuk dipakai dalam mencapai tujuan tersebut; dan Kapan waktunya; melalui

${ }^{20}$ Padwo Wahjono, Indonesia Negara Berdasarkan Atas Hukum (Ghalia Indonesia 1986).

${ }^{21}$ Padwo Wahjono, 'Menyelisik Proses Terbentuknya Peraturan PerUndang-Undangan' (1991) 29 Majalah Forum Keadilan.[65]. 
cara bagaimana hukum itu perlu diubah; dan Dapatkah suatu pola yang baku dan mapan dirumuskan untuk membantu dalam memutuskan proses pemilihan tujuan serta cara-cara untuk mencapai tujuan tersebut dengan baik.

Meminjam kerangka politik hukum dari Satjipto Rahardjo, maka politk hukum perlu merumuskan tujuan apa yang hendak dicapai dari penyelesaian masalah yang akan dilakukan. Penyelesaian masalah terhadap kekosongan hukum dari Permendagri sebagaimana diutarakan di atas, yakni: Pertama, Untuk memberikan kepastian hukum pemisahan antara rezim BMD dan BMN secara tegas, khususnya dalam hal pemanfaatan BMD. Dengan pembaharuan itu, diharapkan pemerintah daerah tidak lagi dalam keragu-raguan untuk merujuk peraturan pusat mana yang harus dirujuk dalam pembentukan Perda tentang pemanfaatan BMD, yakni adalah tunggal Permendagri yang memiliki kewenangan berdasarkan undang-undang, dan tidak lagi merujuk pada Permenkeu, yang secara rezim adalah berbeda. Dengan itu, juga akan menunjang pemerintah daerah tetap dalam koridor good governance. ${ }^{22}$

Salah satu pembinaan yang dilakukan oleh Pemerintah Pusat melalui jajaran kementriannya dalam konteks penyelenggaran pemerintahan daerah adalah menetapkan norma, standar, kriteria dan prosedur yang dituangkan dalam peraturan/kebijakan tertulis, dan kemudian hal itu dijadikan dasar pedoman untuk mengeluarkan kebijakan di level pemerintah daerah. Begitu juga dalam level pengelolaan BMD, pemerintah pusat yang kemudian dalam PP 27/2014 mengamanatkan beberapa kementrian untuk menetapkan kebijakan tersebut.

Pasal 90 PP 27/2014 mengatur: (1) Menteri Keuangan melakukan pembinaan pengelolaan Barang Milik Negara dan menetapkan kebijakan pengelolaan Barang Milik Negara/Daerah. (2) Kebijakan sebagaimana dimaksud pada ayat (1) terdiri atas kebijakan umum Barang Milik Negara/Daerah dan/atau kebijakan teknis Barang Milik Negara. (3) Menteri Dalam Negeri melakukan pembinaan pengelolaan Barang Milik Daerah dan menetapkan kebijakan sesuai

22 Donna Okthalia Setiabudhi, 'Pengelolaan Aset Pemerintah dalam Perspektif Good Governance' (2019) 1 Jurnal The Studies of Social Science.[19]. 
dengan kebijakan umum sebagaimana dimaksud pada ayat (2). Maksud dari ketentuan pasal tersebut, adalah untuk memberikan kewenangan lebih lanjut kepada Kementrian Keuangan dan juga Kementrian Dalam Negeri. Kementrian keuangan ditugaskan untuk melakukan pembinaan terhadap BMN sekaligus menetapkan kebijakan umum BMN dan BMD. Sampai pada penjelasan ini, artinya menteri keuangan menetapkan kebijakan umum berisi pedoman-pedoman yang kemudina pedoman itu juga akan dijadikan dasar/landasan bagi kementrian lain untuk menetapkan kebijakan ynag sifatnya lebih spesifik. Selanjutnya adalah Kementrian Dalam Negeri, berdasarkan pasal tersebut, Kementrian Dalam Negeri memiliki tugas yang lebih spesifik dibandingkan dengan Kementrian Keuangan, yakni menetapkan pembinaan terhadap pengelolaan BMD, hanya untuk BMD. Artinya, dalam melakukan pengelolaan BMD, berdasarkan pasal 90 PP 27/2014 terdapat 2 kementrian yang bertugas untuk melakukan pembinaan, yakni Kementrian Keuangan yang melakukan Kebijakan Umum untuk pengelolaan dan juga Kementrian Dalam Negeri sebagai penetap kebijakan yang sifatnya lebih spesifik, yakni hanya kepada BMD.

Fokus mengenai formula tarif sewa, ${ }^{23}$ saat ini dalam Permendagri 19/2016 tidak memiliki ketentuan rigid mengenai formula tarif sewa, khususnya mengenai faktor penyesuai sewa. Jika melihat ke dalam Permendagri 19/2016, tidak ada ketentuan secara rigid mengenai penghitungan faktor penyesuai sewa. Faktor penyesuai sewa tersebut, kewenangannya dilimpahkan kepada Gubernur/ Bupati/Walikota, sebagaimana ditegaskan dalam pasal 126 ayat (3) Permendagri 19/2016: Faktor penyesuai sewa sebagaimana dimaksud pada ayat (1) ditetapkan oleh Gubernur/Bupati/Walikota.

Dalam praktik selama ini, artinya formula tarif sewa dan penyesuai sewa 'khusus yang berkaitan dengan BMD masih belum memiliki dasar hukum yang spesifik. Dasar hukum yang sering digunakan sebagai dasar pembentukan peraturan di level daerah (baik Perda/Perkepda) masih berpijak pada Peraturan

${ }^{23}$ Pasal 117: Formula tarif sewa barang milik daerah merupakan hasil perkalian dari: a. tarif pokok sewa; dan b. faktor penyesuai sewa. 
Muhajir dan M. Najih: Pembaruan Hukum Penentuan...

Menteri Keuangan Nomor 115/PMK.06/ 2020 Tentang Pemanfaatan Barang Milik Negara. Permenkeu tersebut mengatur tentang BMN, dan didalamnya tidak ada maksud dan norma yang menjelaskan tentang peruntukan peraturan itu untuk menjadi dasar BMD.

Sebagai contoh: Peraturan Bupati Karawang Nomor 90 tahun 2018 tentang Tata Cara Pelaksanaan Pemanfaatan Barang Milik Daerahnan. Perbup ini sudah memilikicara menghitung tentang formula penyesuaisewa, meskipun Permendagri 19/2016 tidak mengatur tentang formula penyesuai sewa. Akan tetapi, Perbup tersebut mengadopsi dan berpijak pada Peraturan Menteri Keuangan Nomor:57/ PMK.06/2016 tentang Tata Cara Pelaksanaan Sewa Barang Milik Negara (Permenkeu terdahulu sebelum 115/PMK.06/2020), yang merupakan rezim BMN.

Permendagri 19/2016 perlu diubah untuk memasukan point tentang metode penghitungan dari formula penyesuai sewa. Tujuannya agar menciptakan kepastian hukum bagi rezim pengelolaan BMD oleh pemerintah daerah agar memiliki pijakan dan dasar yang jelas. Hal ini akan menjadi rujukan utama bagi pemerintah daerah dalam melakukan pengelolaan, khususnya sewa, alhasil jika ini diwujudkan akan menciptakan keserasian dan persamaan persepsi antara satu pemerintah daerah dengan pemerintah daerah lainnya. Keserasian perlu, karena dalam praktiknya terdapat pihak ketiga yang berinvestasi dan melakukan pembangunan yang dilakukan oleh 1 badan hukum/usaha di beberapa daerah. Hal ini juga menunjang kepastian bisnis, berusaha dan investasi.

Rekomendasi yang diberikan dalam kajian ini, adalah merubah Permendagri 19/2016 dengan point 'penambahan' norma terhadap faktor penyesuai sewa, yang dalam Permendagri 19/2016 tidak dijelaskan/diatur lebih lanjut rincian metode penghitungannya. Untuk menjaga keserasian, sekaligus amanat dari PP 27/2014, maka norma yang diusulkan adalah dengan mengadopsi mekanisme penghitungan faktor penyesuai sewa yang ada dalam Permenkeu 115/PMK.06/2020. Berikut usul penambahannya:

1. Besaran faktor penyesuai Sewa untuk kelompok jenis kegiatan usaha bisnis ditetapkan sebesar 100\% (seratus persen).

2. Faktor penyesuai Sewa sebagaimana dimaksud pada ayat (1), dikecualikan 
dari ketentuan terhadap: a. Koperasi yang dibentuk dan beranggotakan Aparatur Sipil Negara/ anggota Tentara Nasional Indonesia/ anggota Kepolisian Negara Republik Indonesia, yang tujuan pendiriannya untuk kesejahteraan anggota; atau b. Pelaku usaha perorangan berskala ultra mikro, mikro, dan kecil.

3. Faktor penyesuai Sewa untuk kelompok sebesar: a. 75\% (tujuh puluh lima persen) untuk Koperasi sekunder; b. 50\% (lima puluh persen) untuk Koperasi pnmer; atau c. $25 \%$ (dua puluh lima persen) untuk pelaku usaha perorangan berskala ultra mikro, mikro dan kecil.

4. Besaran faktor penyesuai Sewa untuk kelompok jenis kegiatan usaha non bisnis ditetapkan 30\% (tiga puluh persen) sampai dengan 50\% (lima puluh persen).

5. Dikecualikan dari ketentuan sebagaimana dimaksud terhadap: a. peruntukan Sewa yang diinisiasi oleh Pengelola Barang/Pengguna Barang untuk mendukung tugas dan fungsi, faktor penyesuai Sewa ditetapkan sebesar 15\% (lima belas persen); atau b. sarana dan prasarana pendidikan dalam rangka pemenuhan kebutuhan anggota keluarga Aparatur Sipil Negara/Tentara Nasional Indonesia/Kepolisian Negara Republik Indonesia dan pegawai penunjang, faktor penyesuai Sewa ditetapkan sebesar 10\% (sepuluh persen).

6. Besaran faktor penyesuai Sewa untuk kelompok Jenis kegiatan usaha sosial sebesar 2,5\% (dua koma lima persen).

7. Besaran faktor penyesuai Sewa untuk periodesitas Sewa ditetapkan sebagai berikut: a. untuk jangka waktu Sewa 1 (satu) tahun: 1. per tahun sebesar 100\% (seratus persen); 2. per bulan sebesar 130\% (seratus tiga puluh persen); 3 . per hari sebesar $160 \%$ (seratus enam puluh persen); 4. per jam sebesar 190\% (seratus sembilan puluh persen). b. untukjangka waktu Sewa lebih dari 1 (satu) tahun: 1. sebesar 100\% (seratus persen) untuk pembayaran Sewa yang dilakukan sekaligus terhadap seluruh jangka waktu Sewa; 2. sebesar 120\% (seratus dua puluh persen) untuk pembayaran Sewa yang dilakukan per tahun terhadap Sewa yang berjangka waktu 2 (dua) tahun; 3. sebesar 125\% (seratus dua puluh lima persen) untuk pembayaran Sewa yang dilakukan per tahun terhadap Sewa yang berjangka waktu 3 (tiga) tahun; 4. sebesar 130\% (seratus tiga puluh persen) untuk pembayaran Sewa yang dilakukan per tahun terhadap Sewa yang berjangka waktu 4 (empat) tahun; 5. sebesar 135\% (seratus tiga puluh lima persen) untuk pembayaran Sewa yang dilakukan per tahun terhadap Sewa yang berjangka waktu 5 (lima) tahun.

8. Besaran Sewa atas BMN untuk kerja sama infrastruktur atau untuk kegiatan dengan karakteristik usaha yang memerlukan waktu Sewa lebih dari 5 (lima) tahun dapat mempertimbangkan nilai keekonomian dari masing-masing infrastruktur.

9. Besaran Sewa dalam rangka penyediaan infrastruktur merupakan hasil perkalian dari: a. tarif pokok Sewa; dan b. faktor penyesuai Sewa.

10. Tarif pokok Sewa sebagaimana dimaksud pada ayat (1) huruf a merupakan nilai wajar atas Sewa hasil perhitungan dari Penilai.

11. Faktor penyesuai Sewa sebagaimana dimaksud pada ayat (1) huruf b 
ditetapkan dengan mempertimbangkan: a. daya beli/kemampuan membayar (ability to pay) masyarakat; b. kemauan membayar (willingness to pay) masyarakat; dan/ atau c. nilai keekonomian, atas masing-masing infrastruktur yang disediakan.

12. Dalam hal diperlukan Pengelola Barang dapat meminta pertimbangan kepada instansi teknis terkait dalam penentuan besaran faktor penyesuai.

Keseluruhan usulan perubahan tersebut mulai dari point 1-12 diadopsi dari Peraturan Menteri Keuangan Nomor 115/PMK.06/2020 Tentang Pemanfaatan Barang Milik Negara, metode pengitungan tersebut adalah metode penghitungan formula tarif BMN. Point itu perlu dimasukan, agar di masa mendatang seluruh daerah tidak lagi merujuk kepada Peraturan Menteri Keuangan Nomor 115/ PMK.06/2020 Tentang Pemanfaatan Barang Milik Negara, karena rezimnya berbeda dari BMD.

Merujuk pada teori regulasi, Regulasi secara langsung memengaruhi proses inovasi, sementara inovasi dan perubahan teknis memiliki dampak signifikan terhadap regulasi. Keberhasilan dapat dicapai melalui upaya reformasi regulasi dengan memperhitungkan keterkaitan antara regulasi dan inovasi. Regulasi administratif (administrative regulation) mengatur fungsi praktis masyarakat. ${ }^{24}$ Reformasi regulasi diarahkan untuk memastikan bahwa regulasi ini benar sepenuhnya responsif terhadap perubahan kondisi ekonomi, sosial, dan teknis yang mengelilinginya. Banyak reformasi didorong oleh perkembangan sosial politik..$^{25}$

Terdapat 3 tipe umum regulasi, yang mana ketiganya berpengaruh terhadap inovasi. Pertama, economic regulation, dimaksudkan untuk memastikan efisiensi pasar, sebagian melalui promosi daya saing yang memadai di antara para pelaku usaha. Kedua, social regulation, dimaksudkan untuk mempromosikan internalisasi semua biaya yang relevan oleh aktor. Ketiga, administrative regulation, bertujuan untuk memastikan berfungsinya operasi sektor publik dan swasta. Hal ini sebagaimana tersaji dalam sebagai berikut:

${ }^{24}$ Dirk Pilat Jens HOJ, Toshiyasu Kato, 'Deregulation and Privatisation in the Services Sector' (2011) 25 OECD Economic Studies.[19].

25 George Symeonidis, 'Innovation, Firm Size and Market Structure: Schumpeterian Hypotheses and Some New Themes', OECD Economics Department Working Paper.[61]. 
Tabel 2. Tipe-Tipe Regulasi

\begin{tabular}{ll}
\hline \multicolumn{1}{c}{ Tipe Regulasi } & \multicolumn{1}{c}{ Keterangan } \\
\hline $\begin{array}{l}\text { Economic Regu- } \\
\text { lation }\end{array}$ & $\begin{array}{l}\text { Economic regulation pada umumnya dimaksudkan untuk meningkat- } \\
\text { kan efisiensi pasar dalam mengirimkan barang dan jasa, termasuk } \\
\text { pembatasan yang diberlakukan pemerintah pada keputusan } \\
\text { perusahaan terhadap harga, kuantitas, layanan masuk dan keluar. }\end{array}$ \\
Social Regulation & $\begin{array}{l}\text { Social regulation dimaksudkan untuk melindungi kesejahteraan dan } \\
\text { hak-hak masyarakat luas. Mencakup perlindungan lingkungan, kese- } \\
\text { hatan dan keselamatan di tempat kerja, perlindungan hak-hak peker- } \\
\text { ja, dan perlindungan pembeli dari perilaku penipuan atau tidak kom- } \\
\text { petennya penjual. }\end{array}$ \\
Administrative & $\begin{array}{l}\text { Administrative regulation berkaitan dengan manajemen pemerintah } \\
\text { dari kegiatan pada sektor publik dan swasta. Mencakup peraturan } \\
\text { yang berkaitan dengan pajak, pengoperasian bisnis, sistem distribusi, } \\
\text { administrasi perawatan kesehatan dan hak kekayaan intelektual. }\end{array}$ \\
\hline
\end{tabular}

Merujuk pada tipe-tipe regulasi diatas, perubahan Permendagri nantinya akan menjadi dorongan inovasi untuk memberikan kepastian dalam kegiatan administrasi dari pemanfaatan sewa BMD, sehingga tidak terjadi kerancuan dalam pemanfaatan karena dalam praktik sebelumnya regulasi BMN dijadikan dasar pijakan untuk membentuk regulasi di level BMD. Dixit berpandangan bahwa governance institutions berpengaruh terhadap economic outcomes secara umum karena good governance sangat penting untuk melindungi tiga esensi prasyarat untuk ekonomi pasar: (1) perlindungan terhadap hak milik; (2) penegakan hukum kontrak; (3) resolusi terhadap permasalahan dalam tindakan kolektif. Relevansi persyaratan ini untuk inovasi menjadi bukti. ${ }^{26}$

\section{Kesimpulan}

Berdasarkan uraian pembahasan diatas maka disimpulkan sebagai berikut: Bahwa dasar hukum pemanfaatan BMD oleh pemerintah daerah khususnya dalam penentuan tarif sewa, ditemukan masalah dalam hukum positif di Indonesia. Masalahnya adalah kekosongan hukum dalam level Permendagri 19/2016. Sebagai peraturan pelaksana BMD dan menjadi NSPK oleh pemerintah daerah, Permendagri 19/2016 masih belum memiliki norma yang rigid mengatur 
Muhajir dan M. Najih: Pembaruan Hukum Penentuan...

tentang faktor penyesuai sewa. Permendagri 19/2016 tidak sampai mengatur tentang peruntukan hingga penghitungan terhadap jenis-jenis kegiatan usaha yang memanfaatkan BMD. Alhasil dalam praktik di beberapa daerah, banyak produk hukum daerah baik dalam level Peraturan Daerah (Perda) dan Peraturan Kepala Daerah (Perwali/Perbu) yang merujuk pada Peraturan Menteri Keuangan, yang peruntukannya adalah untuk BMN, bukan untuk BMD. Terjadi kerancuan dalam produk hukum level kementrian mana yang kemudian menjadi acuan untuk BMD. Hal ini mengganggu kepastian hukum dalam landasan pembentukan produk hukum daerah, dan terjadi potensi setiap pemasukan keuangan pada daerah (PAD) menjadi tidak sah karena tidak ditunjang oleh peraturan perundangundangan yang jelas dan pasti.

Atas sekian masalah yang ada, maka di masa mendatang perlu untuk melakukan perubahan terhadap Permendagri 19/2016. Pembaruan hukum dapat dilakukan antara lain dengan: 1. Untuk memberikan kepastian hukum pemisahan antara rezim BMD dan BMN secara tegas, khususnya dalam hal pemanfaatan BMD.

2. Dengan adanya perubahan itu, semakin memperkuat peran pemerintah pusat sebagai pembina pemerintah daerah dalam menetapkan NSPK yang baik dan benar serta bisa menjadi rujukan seluruh pemerintah daerah, sehingga dalam praktik tidak terjadi perbedaan NSPK yang sebelumnya disebabkan peraturan dalam level pemerintah pusat tidak memiliki kejelasan dan ketegasan. 3. Pemerintah daerah yang diberi otonomi seluas-luasnya, yang salah satu bentuknya adalah bebas untuk mencari pendapat keuangan yang sah melalui (PAD), maka pemerintah daerah memiliki kewajiban untuk memastikan setiap pendapatan yang diterima oleh pemerintah daerah sesuai dengan peraturan perundang-undangan yang jelas dan pasti. Jika aturan yang menjadi landasan pemasukan itu tidak pasti, maka implikasinya adalah pemasukan itu akan menjadi pemasukan yang tidak sah dan menjadi sesuatu yang tidak dapat dipertanggungjawabkan. Dasar hukum yang jelas, tegas dan pasti adalah penunjang pemerintah daerah dalam mencari PAD dan sesuai dengan asas-asas umum pemerintahan yang baik. Saran diberikan kepada Kementrian Dalam Negeri untuk melakukan revisi terhadap Permendagri 
19/2016 dengan memasukkan norma faktor penyesuai sewa dengan mengadopsi norma yang ada dalam Peraturan Menteri Keuangan Nomor 115/PMK.06/2020 Tentang Pemanfaatan Barang Milik Negara. Paska perubahan tersebut, maka nantinya seluruh pemerintah daerah bisa merujuk pada produk hukum yang dikeluarkan oleh Kementrian Dalam Negeri, sehingga objek pengaturannya jelas dan pasti yakni adalah BMD, tidak lagi merujuk pada Peraturan Menteri Keuangan Nomor 115/PMK.06/2020 Tentang Pemanfaatan Barang Milik Negara, yang rezimnya merupakan BMN.

\section{Daftar Bacaan}

\section{Buku}

Atmosodirjo P, Hukum Administrasi Negara (Ghalia Indonesia 1983).

Conway, F., Kaganova, O., \& McKellar JA, Composite Image" of Central Government Asset Management Reforms (Managing government property assets: International experiences 2006).

Hann RW, Reviving Regulatory Reform: A Global Perspective (AEI Brookings Joint Center for Regulatory Studies 2000).

Ibrahim J, Teori dan Metodologi Penelitian Hukum Normatif (Bayumedia 2011).

Padwo Wahjono, Indonesia Negara Berdasarkan Atas Hukum (Ghalia Indonesia 1986).

Safri Nugraha et. al., Hukum Administrasi Negara (Center for Law and Good Governance Studies FH UI 2007).

\section{Jurnal}

Agus Purnomo et. al., 'Analisis Pengelolaan Barang Milik Daerah Dalam Meningkatkan Pendapatan Asli Daerah' (2021) 7 Jurnal Kebijakan dan Pelayanan Publik.

Era Nandya Febriana, Jayus RI, 'Pengelolaan Barang Milik Daerah Berdasarkan Peraturan Pemerintah Nomor 27 Tahun 2014 tentang Pengelolaan Barang Milik Negara/Daerah' (2017) 4 Journal Lentera Hukum.

Fikha Kristy Bolendea, Ventje Ilat JW, 'Analisis Penggunaan dan Penatausahaan Barang Milik Daerah di Pemerintah Kota Manado' (2017) 12 Jurnal Riset 
Muhajir dan M. Najih: Pembaruan Hukum Penentuan...

Akuntansi Going Concern.

Fitria Ningrum, 'Penerapan Sistem Pengelolaan Barang Milik Daerah dan Kewajaran Laporan Keuangan Pemerintah Daerah' (2017) 2 Jurnal Ekubis.

Hasfi N, 'Pengelolaan Barang Milik Daerah (Suatu Studi Pada Dinas Pendapatan, Pengelolaan Keuangan dan Aset Kabupaten Sintang)' (2013) 1 Jurnal Tesis PMIS UNTAN PSIAN.

Jens HOJ, Toshiyasu Kato DP, 'Deregulation and Privatisation in the Services Sector' (2011) 25 OECD Economic Studies.

Noviawati E, ‘Optimalisasi Pengelolaan Aset Daerah terhadap Penyelenggaraan Otonomi Daerah' (2016) 4 Jurnal Galuh Justisi.

Padwo Wahjono, 'Menyelisik Proses Terbentuknya Peraturan PerUndangUndangan' (1991) 29 Majalah Forum Keadilan.

Runiawati N, 'Pemanfaatan Barang Milik Daerah (Suatu pendekatan teoritis dan praktis dalam menentukan metode pemanfaatan aset)' (2017) 1 Jurnal Manajemen Pelayanan Publik.

Setiabudhi DO, 'Pengelolaan Aset Pemerintah dalam Perspektif Good Governance' (2019) 1 Jurnal The Studies of Social Science.

Siti Amerieska, Fita Setiati IM, 'Analisis Faktor Tentang Efektivitas Pengelolaan Barang Milik Daerah (Studi pada Badan Pengelolaan Keuangan ddn Aset Daerah Kabupaten Malang)' (2018) 1 Jurnal Ilmiah Bisnis dan Ekonomi Asia.

Symeonidis G, 'Innovation, Firm Size and Market Structure: Schumpeterian Hypotheses and Some New Themes' 161 OECD Economics Department Working Paper.

\section{Perundang-undangan}

Keputusan Presiden (Keppres) Nomor 7 Tahun 2020 tentang Gugus tugas Percepatan Penanganan Corona Virus Disease 2019 (Covid-19).

Keputusan Presiden Nomor 12/2020 tentang Penetapan Corona sebagai Bencana Nasional.

Peraturan Menteri Keuangan Nomor:57/PMK.06/2016 tentang Tata Cara Pelaksanaan Sewa Barang Milik Negara.

Peraturan Menteri Dalam Negeri Nomor 19 tahun 2016 tentang Pengelolaan 


\section{Barang Milik Daerah.}

Peraturan Pemerintah Nomor 27 Tahun 2014 tentang Pengelolaan Barang Milik.

Undang-Undang Nomor 1 Tahun 2004 tentang Perbendaharaan Negara.

Peraturan Menteri Keuangan Nomor 115/PMK.06/2020 Tentang Pemanfaatan Barang Milik Negara.

How to cite: Muhajir dan M. Najih, 'Pembaruan Hukum Penentuan Faktor Penyesuaian Sewa Barang Milik Daerah oleh Pemerintah Daerah’ (2022) Vol. 5 No. 1 Media Iuris. 
--Halaman ini sengaja dibiarkan kosong-- 